\title{
The Success of Youth-Oriented Environmental NGO: A Case Study of Koalisi Pemuda Hijau Indonesia
}

\author{
Suharko ${ }^{1}$ \\ ${ }^{1}$ Department of Sociology, Faculty of Social and Political Sciences, Gadjah Mada University, Indonesia \\ Correspondence: Suharko, Jl.Sosio Justisia, No.2, Bulaksumur UGM, 55281, Yogyakarta, Indonesia. Tel: \\ 62-274-56-3362. E-mail: suharko@ugm.ac.id
}

Received: August 14, 2015 Accepted: August 22, 2015 Online Published: September 21, 2015

doi:10.5539/ass.v11n26p166 URL: http://dx.doi.org/10.5539/ass.v11n26p166

\begin{abstract}
This article presents a case study of a youth oriented-environmental NGO, Koalisi Pemuda Hijau Indonesia (KOPHI), which has experienced rapid growth in recent years in Indonesia. As a network organization, KOPHI has been able to accommodate youth in many cities throughout Indonesia, especially in prompting university students to get involved in numerous environmental actions. Its main activity is environmental conservation that is able to involve children, youth and communities in a number of cities. In contrast to established environmental NGOs, KOPHI has also been able to develop a mechanism for self-financing, so that it is not dependent on foreign aid agencies. The capacity of KOPHI in implementing the three dimensions of the strategic triangle (value creation, support \& legitimacy, and operational capacity) is a key to the success in the sustainable growth of the organization and in its role in conserving the environment in Indonesia.
\end{abstract}

Keywords: youth, NGOs, environmental movement, strategic triangle, Indonesia

\section{Introduction}

\subsection{The Development of Environmental NGOs in Indonesia}

The environmental movement has grown into a global effort in overcoming various environmental crisis's and problems on a global scale. Although this movement initially stemmed from Western industrialized countries, it is now in motion in nearly all countries throughout the world. The environmental movement is supported by millions of global citizens and exceeds any social or spatial boundaries. It is no exaggeration to say that the environmental movement has been described as "the most comprehensive, influential movement of our time" (Castells, 2010, p. 72).

Some agencies that are actively involved in the environmental movement are environmental NGOs (ENGOs). ENGOs are involved and have a role in almost every country in the world. In the context of Indonesia, ENGOs as independent organizations with a focus on environmental issues began to grow and develop in the 1970s (Hendarti \& Nomura, 2005). At that time, ENGO involvement was a response to environmental damage occurring due to citizens' limited awareness of environmental conservation. As an example, the WWF (World Wildlife Fund) found that deforestation was the cause of diminishing orangutan habitats in Sumatra in the early 1970s. YIH (Yayasan Indonesia Hijau - Green Indonesia Foundation) was established in 1978 in follow-up to a WWF project. YIH initiated activities in nature conservation education, in collaboration with schools in Bogor city, which then spread to Bandung, Surabaya, Makassar and Palembang cities. In that same year, Kelompok Sepuluh Pengembangan Lingkungan Hidup (Environmental Development Group of Ten) was established, consisting of 10 NGOs that assisted the government in resolving environment issues. In 1980, WALHI (Wahana Lingkungan Hidup Indonesia or the Indonesian Forum for the Environment) was established in Jakarta as a forum of environmental activists, groups and organizations with an orientation on environmental issues and actions. The establishment of these ENGOs marked the beginning of the ENGO movement in Indonesia (Hendarti \& Nomura, 2005, p. 35; Sinanu, 2006; Suharko, 2005).

ENGO development intensified in the late 1980s up until early 1990s. ENGOs began to move into policy advocacy, in addition to continuing to develop various environmental actions, such as encouraging environmental awareness in communities, and implementing environmental education activities both in and out of schools. In the late 1980s, WALHI appeared to distance itself from the government through various policy 
advocacy actions on environmental issues. WALHI took on policy advocacy due to a variety of environmental problems that actually derived from government policy.

The strengthened environmental advocacy orientation that was apparent in WALHI, was also evident in the establishment of an array of ENGOs in a number of regions that focused on encouraging policy reform pertaining to conservation of natural resources and the environment. Lembaga Alam Tropika (LATIN) or the Institute of Tropical Nature Indonesia in Bogor offered alternative forest resource management through 'community forestry'. Warung Informasi Konservasi (WARSI) or Conservation Information Forum was a network of 12 NGOs working in 4 provinces in Sumatra, focusing on conservation of biodiversity and 'community development' through training and education for local communities. Yayasan Wisnu or the Wisnu Foundation in Bali prioritised water and soil management and pollution issues and disseminating information to communities.

Environmental education activities continued to be developed by ENGOs at the same time. In the late 1980s, WALHI in collaboration with environmental groups started to develop a conservation education program through trainings, called Pendidikan Konservasi Alam (PKA) or Nature Conservation Education for nature loving groups in senior high schools and universities. In 1990, the Seloliman Pusat Pendidikan Lingkungan Hidup (PPLH) or Environmental Education Centre in Mojokerto, East Java was founded. PPLH was actually a development that came out of the environmental education programs implemented by YIH in the 1970s. PPLH was established to effectively manage the YIH programs that were disbursed throughout a number of cities. PPLH was a center for intensive environmental education activities, where students and teachers could visit to enjoy nature and learn (Nomura et al, 2003). In the early 1990s, environmental education activities were also developed by Rimbawan Muda Indonesia (RMI) or Indonesian Young Foresters in Bogor and Yayasan Pengembangan Biosains dan Bioteknologi (YPBB) or the Foundation for the Development of Bioscience and Biotechnology in Bandung (Hendarti \& Nomura, 2005). The establishment of so many NGOs involved in environmental education prompted measures to develop cooperation among them. In 1996, a number of ENGOs formed Jaringan Pendidikan Lingkungan (JPL) or the Environmental Education Network as a collaborative forum for exchanging information, experience and resources to promote environmental education in Indonesia (Nomura \& Abe, 2001).

In the late 1990s, JPL further expanded cooperation with the Ministry of Education, the Ministry of the Environment, and other government agencies to develop environmental education. Some JPL members also joined a team at the Ministry of the Environment to develop environmental education policies (Hendarti \& Nomura, 2005, p. 40).

In addition, the environmental movement, which was more environmental advocacy oriented simultaneously strengthened. Jaringan Aksi Tambang (JATAM) or Mining Advocacy Network, Sawit Watch, and other advocacy NGOs, utilised the open political space to conduct advocacy actions against companies, government agencies, and other actors believed to be environmentally destructive. They mobilized various advocacy actions, ranging from protests in the media and online media, demonstrations through to lawsuits.

In the post-authoritarian New Order period, not only were the established ENGOs active in a variety of environmental actions, but also the newly emerging ENGOs. From the author's observations, from searching online media and social media, these ENGOs were actively implementing an array of environmental activities. The main target groups of these new ENGOs were generally young people. The ENGOs themselves were organized by young Indonesian middle class, who were mainly students from renowned universities in Indonesia such as Bandung Technology Institute, Bogor Institute of Agriculture, University of Indonesia in Jakarta, and Gadjah Mada University in Yogyakarta as well as other universities in various cities. Nilan (2015) refers to these ENGOs as youth-oriented ENGOs.

\subsection{The Emergence of Youth-Oriented ENGOs}

The youth-oriented ENGOs have been flourishing since early 2000. At the national level, this has included KOPHI (Koalisi Pemuda Hijau Indonesia), GYC (Garuda Youth Community), Indonesia Berkebun (Indonesia Farming), Sahabat Alam (Friends of Nature) etc. At the local (city) level, in Jakarta there is Trashi (Transformasi Hijau/Green Transformation), ICSF (Indonesia Climate Change Student Forum), and TGG (Teens-Go-Green). Tunas Hijau (Green Shoots) is active in environmental activities in Surabaya. Bicons (Bird Conservation Society), Culindra, Sahabat Kota (Friends of the City), Taman Kota (City Park), Riset Indie (Indie Research), and Greeneration are all active in Bandung. Even in small cities like Salatiga, Tanam untuk Kehidupan (Planting for Life) has been active in promoting environmental sustainability.

KOPHI appears to be the most successful of these youth-oriented ENGOs. First, in a short period of time since its inception in 2010 up until 2013, as a coalition-based organization, KOPHI owns a central office in Jakarta and 
16 local chapters. The initial idea of its establishment was pioneered by three university students in Jakarta. Along with other local activists studying in Jakarta and other areas surrounding Jakarta, they founded KOPHI, which was followed by the establishment of the local chapters. In 3 years, KOPHI became a nationally recognised organization. Second, as this organization has rapidly grown through its networks, KOPHI has a robust managerial capacity to accommodate youth -especially university students to participate in and organize numerous environmental actions. It is estimated that on average there are 20-30 members in each chapter of KOPHI and this membership increases annually through open recruitment. At the end of 2013, there were around 1000 members in total. Third, KOPHI has been actively engaged in environmental activities that have involved children, adolescents and young adults in many cities in Indonesia. Fourth, KOPHI has significantly increased its self-financing capacity, thus not relying on donors or foreign aid agencies like conventional NGOs generally do. In short, KOPHI has provided the best practices for ENGO engagement in the environmental movement during the last decade in Indonesia.

The emergence and development of youth-oriented ENGO such as this still the lack attention of researchers on environmental movements, especially in developing countries. Studies on the environmental movement by ENGO are generally focused on established ENGOs and their role in promoting environmental conservation and environmental policy advocacy. Nomura and Abe (2001) examined the important role of ENGO networks in Asia in promoting and supporting transboundary environmental education. These networks serve as an "infrastructure", which facilitates and bolsters environmental education, as well as international cooperation in Asian countries. A study in Asia-Pacific regions (China, the Philippines, Vanuatu) shows that ENGOs have played a role and contributed to promoting environmental education and conservation activities leading towards sustainability. These ENGO achievements have initiated momentum in developing education for sustainable development in the region (Tilbury et al., 2003). In line with the implementation of the open door policy and the environmental problems that are escalating in China, ENGOs are developing and actively involved in environmental protection despite restrictions on their activities from the government (Maohong, 2009). In Indonesia, in a different political context, ENGOs became an important part of the environmental movement in Indonesia during the New Order authoritarian regime (Eldridge, 1995) and in the more democratic post-New Order (Nomura, 2007).

Moreover, these studies also failed to focus attention on the issue of the success or failure of ENGOs in environmental movement organizing. In the context of Indonesia, with reference to the "change agent" perspective, Nomura et al. (2003) provided a good example of an NGO environmental education center (PPLH-Seloliman) in promoting environmental education and self-sufficiency to support these activities. In the context of the rapid development of youth-oriented ENGOs after the fall of the authoritarian New Order regime, it is important to demonstrate the success of the newly emerging ENGOs in organizing environmental movements.

Based on KOPHI's success in growing to become one of the most prominent youth-oriented ENGOs in such a short period of time, this article depicts the processes and strategies that have helped this organization to achieve its goals. Through scrutinizing the trajectories of this organization, this article intends to shed light on factors that have contributed to KOPHI's success, therefore examining the meaning and practices of the environmental youth movement in a post authoritarian context. By referring to the concept of the strategic triangle that is often used to explore the values and practices of non profit organizations (Brown \& Moore, 2001), this article argues that strategies deployed by an ENGO will determine its success in organizing youth to be involved in environmental actions.

\section{Conceptual Framework}

The concept of the strategic triangle is basically a conceptual framework to examine the accountability of NGOs that are part of NPO. Although the article does not embrace issues of accountability, nevertheless, following the argument espoused by Brown \& Moore (2001), accountability is closely linked to strategic dimensions of voluntary and non-profit entities. Therefore, how these dimensions co-exist and work will determine the success of NPOs in delivering their promises.

Accountability is something that cannot be ignored by NPOs, because they have pledged to do their best and they have a moral and legal obligation to do so. The rapidly growing number of social movements and actions of various NPOs worldwide has raised critical questions and concerns in regard to their accountability.

In addition, accountability is imperative as NPO entities usually use other groups (mainly aid donors) to attain certain goals. NPOs, especially NGOs in relation to state agencies, corporations, and other development agencies, often claim to be working on behalf of the interest of others such as the poor, minority groups, and other 
marginal groups. This indicates that in practice NPOs actually have complex relations with other stakeholders, where interests and claims from actors involved are varied and not always aligned to each other. A NPO is encouraged to not only extend its networks with many actors, but also keep its interests in line with other actors' interests to achieve its goals and missions.

According to Brown \& Moore (2001, p. 574) issues concerning accountability are not abstract, moral, or legal issues. On the contrary, issues of accountability should be regarded as strategic choices that would uphold an NPO in defining and achieving its highest institutional values. NPO relations with other actors are not always equal and their interests are not always aligned to each other, which may affect missions, strategies, and operational aspects of an organization. In this case, NPOs need to draft missions and organizational strategies for accommodating other actors' interests while embodying the aims and values of the organization.

In the context of NPOs, the strategic triangle concept illuminates the relationship between accountability and strategy (Moore, 2000). The strategic triangle is detailed in Figure 1 below. The triangle consists of value, support and legitimacy, and operational capacity. These three elements are critical dimensions for an NPO to survive, generate invaluable outcomes, and successfully adapt to changing circumstances (Brown \& Moore, 2001, p. 575).

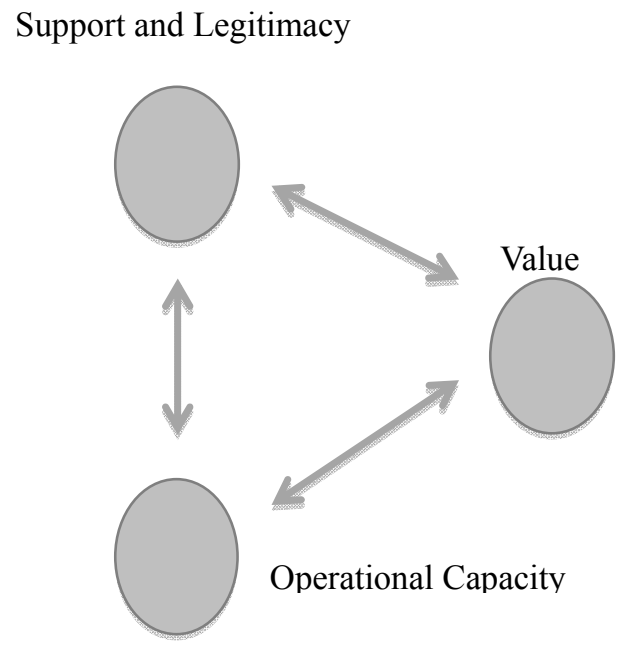

Figure 1. Strategic triangle (Brown \& Moore, 2001, p. 576)

In regard to the first element, value, a NPO is established to achieve certain public goals - for instance, improving the lives of the poor, ensuring human rights are fulfilled and improving environmental conditions etc. In this context, a NPO must deliver and emphasize certain values that it wants to manifest and how these will be achieved. The formulation of these values will direct the organizational goals, helping to mobilize and foster support from other actors, and create a particular focus for developing and strengthening an organization's operational capacity.

The second element is support and legitimacy. A NPO would not be able to achieve its goals without the cooperation of other actors. In this context, a NPO should be able to gain the political, legal, and financial support needed for achieving its goals. With such cooperative relationships among diverse actors, a NPO will secure more legitimacy and additional support.

The issue of NPO support and legitimacy is much more complex than that of business and financial organizations which only focus on customers as supporting and legitimate resources. A NPO will only exist and remain sustainable if it can gain a variety of support from many actors. The capacity of a NPO in building relations with these 'contributors' directly affects the organizational management and operational capacity.

One of the most discussed critical concerns in the issue of support and legitimacy is organizational relations with 'contributors' or funding agencies. Financial support and material resources enabling the operational work are obtained from 'contributors' (individuals, funding agencies, government, and corporations). A high level of dependency on contributors may lead to a problematic situation in a NPO. If a NPO overly follows the preferences of donors, then the interests of the clients or target groups is potentially compromised. In this situation, donors may dictate the preferences of a NPO. In turn, this may raise more ethical, legal, and strategic 
concerns and inquiries - for instance, to whom non-profit is supposed to be responsible.

The issue of support and legitimacy does not only pertain to the funding flow but is also related to resource flows. Many NPOs are too reliant on the contribution of time and efforts voluntarily generated by their members, staff, and volunteers. They are unpaid or possibly underpaid (compared to standard salaries in the private sector of the same level or skills). Many NPOs also gain resources in terms of in-kind donations in the form of aid, equipment, and so forth from contributors.

In the context of NPOs, legitimacy is also affected by political and social recognition from external parties and the public in general. Many kinds of support from various parties can leverage the level of legitimacy of a NPO and thus enable it to continuously operate to achieve its goals and justify their contributions. Simply put, support and recognition from an array of parties may pave the way of a NPO to ultimate organizational success.

The third element is operational capacity. This refers to the capacity to deliver program outcomes. Political, legal, material, and financial resources are utilized to attain expected outcomes. The term 'operational capacity' (rather than organizational capacity) is the organizational ability to deliver results. Operational capacity emphasizes "the capacity needed to deliver results that lies outside the organizational boundaries" (Brown \& Moore 2001, p. 577). Corresponding to this, to achieve targeted goals, a NPO must focus on mobilizing and maintaining partnerships and coalitions with other actors rather than retaining an exclusive position to use its own resources.

As for targeted goals, the previously mentioned strategies should be interrelated, mutually supportive, and operate simultaneously. If a NPO only has support and values but does not have sufficient operational capacity, it is unable to manifest its pledges. If a NPO has sufficient operational capacity but lacks support, it will fail to gain legitimacy. Furthermore, if a NPO gains support and has sufficient capacity but has lacks a reference of values, it may survive but will merely expend resources without any meaningful achievements (Brown \& Moore, 2001, p. 577).

\section{Method}

The article uses an intrinsic case study approach (Stake, 1995) to illustrate the success of KOPHI in organizing youth in Indonesia. The intrinsic case study aims to gain particularization, not generalization. In order to attain this aim;

We take a particular case and come to know it, not primarily as to how it is different from others but what it is, what it does. There is emphasis on uniqueness and that implies knowledge of others that the case is different from, but the first emphasis is on understanding the case itself" (Stake, 1995, p. 8).

This work is usually done through: interpretation that is continuous; not only classifying and patterning data but also reflecting upon it; devoting time to the location; associating with the activities of a case; reflecting and revising the meaning of what has occurred. In order to comprehend a case, "Ultimately, the interpretations of the researcher are likely to be emphasized more than the interpretations of those people studied" (Stake, 1995, p. 12).

The conceptual framework above was applied as a tool of interpretation for data collected from fieldwork that investigated KOPHI Jakarta as the central chapter, and its branches in Yogyakarta and West Java. These two branches were selected, considering the intensity of activism and their progressive organizational programs. Additionally, there are many state and private universities in these provinces that have turned out to be fertile ground for nurturing and developing environmental activism.

Data was collected mainly through interviews with the founder, chairperson and former chairperson of central KOPHI in Jakarta, and also staff and members of the KOPHI chapters in Yogyakarta and Bandung. All informants were chosen through a snowballing method prior to being interviewed. Direct observation was also undertaken to look at various activities in KOPHI. Interviews and observations were conducted in May-June 2013. In addition, secondary data was collected from archives and all online media used by KOPHI, such as organizational websites, blogs, Facebook groups, Twitter, and tumbler up until the end of 2013. All of the collected data was interpreted using the conceptual framework above to gain particularity on the success story of $\mathrm{KOPHI}$ in organising youth.

\section{Results and Discussion}

\subsection{Value Creation}

Indonesia is home to abundant natural resources. However, due to improper management of these resources, there have been devastating impacts to the environment and an ecological crisis has emerged that is very serious (see Indonesia National Agency for Disaster Management, at www.bnpb.go.id). Reoccurring disasters such as 
floods and landslides have become intense due to excessive exploitation of nature, which causes massive damage in Indonesia annually. In this respect, KOPHI was established to explicitly 'unify youth in being responsible and responsive to creating sustainability in Indonesia'.

The main values pursued by this organization and the platform of each activity are environmental conservation values, as exhibited on KOPHI's slogan "Sustainable Indonesia" (Indonesia yang Lestari). Conservation values are also mirrored in their routine greeting of "Greetings, sustainability fellows" (Salam Lestari).

The envisioned conservation values are manifested in KOPHI's organizational by-laws and statues that were set out in the organization's annually held national congress. Further, conservation values are encapsulated in the 2025 Strategic Planning document, which was established at the KOPHI national congress in 2013. An endeavour to integrate conservation values into workable programs was also discussed at the national congress forum involving KOPHI representatives from local and central chapters.

In order for conservation values to enter the public realm, KOPHI has become an agent of environmental education for children, youth, and the community. KOPHI introduces and practices knowledge and skills on environmental management through creative programs with children and youth. In regard to children, the learning principles demand creative processes by utilising games. Outdoor learning activities like studying in the garden is one of the educational tools chosen as an effective learning method to inculcate environmental values and to convey messages on the skills and knowledge of environmental management for conserving nature.

Most of KOPHI's local branches have developed environmental education for primary through to secondary school students. KOPHI Yogyakarta names this activity, 'Alternative Green Edutainment'. This program was developed for primary school students in grade four. In 2013, this program was implemented in Percobaan Dua Primary School and Deresan Primary School, both in Yogyakarta. The activity started with watching and discussing environmental animated movies, such as 'the Lorax'. This movie instils students with the values and practices encompassed in environmental consciousness, such as throwing rubbish into the bin and conserving water and electricity, and so on. Additionally, the children are taught how to separate waste and recycle (3R for 'reduce-reuse-recycle') through tutorials for all students to create artworks from used-goods, such as bottles and ribbons. The artworks are mainly for home decoration items such as flower buckets, piggy banks, and lanterns.

As for the secondary school students, the activities are labelled 'Green Agent' which aims to produce green agents who care about people and the environment in their surroundings so that they can become exemplary examples for friends at school. This activity was conducted at State Secondary School 1 in Yogyakarta, where 110 students participated. The main environmental education content was delivered through games and practical hands on activities on environmental sustainability. Another student conservation activity consisted of creating numerous bio pore holes in local residential areas as a measure to assist with absorption of rain water.

KOPHI is like a 'home' to members where they gather, learn together, and develop to foster pro-environmental behaviour. From the outset, KOPHI was designed as a membership based organization that enables intensive interaction and learning processes amongst its members. After new members join KOPHI, they participate in a 'family gathering', where all members and staff collectively reflect on what members as individuals can do for the organization. This event strengthens the emotional bond between members. A spirit of togetherness is fostered among volunteers, members, and board members, and later through various informal activities i.e. gatherings and having meals together. KOPHI members also enrich their knowledge and skills through organizational activities i.e. writing final reports on events, writing press releases, designing pamphlets and newsletters, and conveying online messages through blogs, websites, and social media. Members gain knowledge through discussions and regular meetings pertaining to environmental issues. Knowledge shaping processes occur through member's involvement in national and local events held by other NGOs.

The congenial interaction among KOPHI personnel is conducive for building environmentally friendly and pro-environmental attitudes. This was evident in the observations, where KOPHI personnel reminded each other on reducing tissue consumption, reused paper and were careful to conserve energy. In the course of everyday life, KOPHI personnel are expected to behave in an environmentally respectful manner, i.e. reducing motorbike use for commuting, saving electricity, and avoiding the use of plastic bags. Activities within the organization enable them to form pro-environmental attitudes.

Furthermore, in order to promote conservation values, KOPHI actively utilizes online media. Accessibility to online media, especially social media like Facebook, Twitter, and the like has allowed KOPHI to launch campaigns to the general public. Particular moments that are associated to environmental conservation, such as Earth Day Celebrations and Environmental Day, Earth Hour events, and Global Water Day are used to spread environmental messages that are uploaded onto websites, blogs, citizen journalism media, Facebook, and Twitter. 
The choice of campaigning through online and social media is fitting for youth as they are the largest users of online social media.

KOPHI's activities are conservation oriented (Castells, 2010; Rootes, 2004). KOPHI has developed an identity as nature lovers and it strives to resist uncontrolled development. In this regard, KOPHI includes mainstream environmentalism similar to the orientation of large ENGOs in developed countries, in particular the Group of Ten, USA (Castells, 2010, p. 172). Due to this orientation, the values offered by KOPHI tend to be easily accepted by many different parties, in particular the government that has long been working in cooperation with conservation oriented ENGOs.

In creating conservation values, KOPHI actively uses online media to launch its activities. In reference to Castells (2010, p. 186), the success of the environmental movement is closely related to the capacity of its actors in leveraging the media. KOPHI's activities are uploaded to their website, Twitter and Facebook and also gain online media coverage. In this way, KOPHI is able to reach a much broader audience beyond their direct constituency.

\subsection{Supports and Legitimacy}

A more democratic political atmosphere in the post-New Order since the late 1990s has provided the assurance of civil and political rights, particularly in being actively involved in organizations and voicing aspirations. Consequently, civil society organizations (CSOs) had a massive resurgence and their activities have ranged from leisure-cultural based through to political related concerns. CSOs including KOPHI appear to have freedom, without feeling threatened by political repressive state apparatus.

Government bodies working on environmental-associated issues are usually supportive of the actions and programs implemented by KOPHI. The Regional Environmental Board and State Agricultural Division, and Fishery Division have funded KOPHI activities. In general, government bodies now position non-governmental organizations as partners rather than as 'opposition' (in contrast to the New Order). Their pro-environmental actions are seen to be more complementary than supplementary to the government's programs.

The choice of conservation oriented issues, like that of KOPHI, does not appear to drive CSOs to get involved in the political sphere. This is different to advocacy-based CSOs, such as WALHI, which often engage in advocacy actions and policy making processes as well as environmental protests. Such actions have led WALHI to directly confront the government and private corporations. Furthermore, this means that the environmental movement's chosen conservation orientation in the context of democratic Indonesia, does not place KOPHI into oppositional conflict in the political sphere or even in a legal context with government bodies and corporations.

In regard to funding issues, central and local chapters of KOPHI use the membership fees and sponsors' donations for daily management costs. The central office of KOPHI charges a membership fee of IDR 30.000/3 months to all members. Instead of raising the membership fee to fund programs and actions, the organization fundraises through 'garage sales' by engaging more people to donate used goods. These profits are used to run pro-environmental actions.

In terms of managing funds, KOPHI has a 'national savings' and both national and local chapters must contribute to it. All funds in the 'national savings', which are coordinated by the general treasurer in KOPHI's central office, can be used for actions and holding the national congress.

This fund-raising model and the mechanism for distributing funding means KOPHI is not so concerned with issues of dependency like other ENGOs that are reliant on foreign aid (Edwards, 1995; Hulme \& Edwards, 1997). KOPHI is relatively autonomous in formulating its own agenda for actions and the likelihood of foreign donors dictating KOPHI's agenda is very low. The sponsors may be invited to KOPHI events but KOPHI is fully autonomous in determining its own way forward and the model of actions.

The financial model for programs that KOPHI manages, to some extent, has supported the work and continuity of programs but funding is not the only necessary aspect of financing actions. Rather than using membership fees to finance actions, KOPHI depends on its co-existence, in terms of the time and efforts of members, volunteers, and staff. All personnel are unpaid, and actually have to 'pay' a certain amount of money to the organization themselves. This has been possible because members of KOPHI are generally from the middle class that to some extent have adopted post-materialist values (Paloniemi \& Valnio, 2011).

KOPHI develops legitimacy through two ways. Firstly, KOPHI works as an organization with a primary platform of voluntarism. Since its establishment, KOPHI set out to accommodate the spirit of voluntarism of youth. This spirit has shaped the basis of organizing programs and actions. In the recruitment process, all member candidates are informed that KOPHI is an environmental organization with a voluntary basis. It is 
mandatory that all members and volunteers contribute by various means, i.e. money, time, and effort. All members are encouraged to work in a team and to assist one and other. Daily interaction in this organization is characterised with an informal and congenial atmosphere. This has allowed voluntarism to become a form of social capital in running the organization and action programs.

Secondly, significant decisions in the organization are made through a participatory consensual mechanism. A number of mechanisms in decision-making are determined and implemented at the local and central levels to enable the participation of members and provide more representativeness. At the national level, the national congress is held annually as a forum to approve KOPHI rules and regulations. The national congress also sets out by-laws, statues, and long-term planning in the form of strategic planning. In addition, the congress event discusses standard operating procedures, technical guidelines, and working plans.

The central KOPHI chairperson is voted and inaugurated at the national congress every two years. The chairperson and staff within the organizational structure who have completed their 2 year contract may be re-elected for the next period. As for the chairpersons located in the local chapters, elections are held in each chapter, and these chairpersons are inaugurated at the national congress.

A reward and penalty mechanism is also reinforced at this forum. Each KOPHI local chapter must present accountability reports. Those chapters that perform with excellence will receive an award. At the national congress in 2012, the KOPHI Yogyakarta chapter received an award for the best accountability report. Local chapters of KOPHI that do not submit an accountability report and send delegates to the national congress will be sanctioned. Prior to a sanction being implemented, it will first be discussed at the national congress and is usually in the form of a reprimand or termination of all organizational activities. The KOPHI West Java chapter is currently sanctioned, because it was inactive. It was decided at the national congress to temporarily terminate their activities, and allow them to reformulate the organizational structure.

Mechanisms for participatory consensual processes are also implemented by the local chapters of KOPHI in each city. Regular meetings are held for decision-making processes, exchanging ideas and action programs. The local chapters of KOPHI conduct an annual deliberative forum (musyawarah besar). In addition to discussing diverse organization-related matters and action programs, the chairperson elections are also held. After a chairperson is elected then the organizational divisions are structured for running pro-environmental actions.

\subsection{Operational Capacity}

The operational capacity of KOPHI is closely linked to its institutional design, organizational structures, and its ability to foster partnerships with stakeholders. As a coalition, the relationship between central and local chapters is not a hierarchical based relationship. As explained in the previous section, the national congress is the highest level forum in which decision making processes take place. The orientation of values and programs are collaboratively planned and set out in this forum. Given such a decision making model, the central and local chapters are given relative autonomy to arrange and run their action programs in accordance to environmental programs in their regions. In practice, coordination between central and local chapter occurs between the divisional levels of the organization. For instance, the head of the research and development division of central and local chapters of KOPHI work together in undertaking a collaborative research project to find solutions in response to certain environmental issues.

KOPHI has established organizational structures as a reference for the central and local chapters and this was determined at the first national congress in 2011. The core organizational structures of central and local chapters are alike, consisting of a chairperson as the main coordinator and individual who is responsible to the organization. The chairperson is assisted by a deputy chairperson, secretary, and treasurer. Three main divisions run the programs, namely the Human Resource Development Division, the Media and Communications Division, and the Research and Development Division.

The difference in organizational structure between central and local chapters is that chairpersons of local chapters are an integral part of KOPHI's central chapter. His/her position lies under the general chairperson and is equal to the secretary and treasurer. This enables 'room' for the 17 local chapters spread across 17 provinces to be involved and communicate directly, which facilitates coordination processes and partnerships between central and local chapters in KOPHI.

KOPHI fosters partnerships with stakeholders in running its programs and arranging actions. Without sufficient resourceful support of stakeholders, programs and actions would be ineffective. In this regard, the capacity of $\mathrm{KOPHI}$ in accessing and leveraging the resources of stakeholders determines the success of the environmental actions. KOPHI has initiated collaborative efforts and utilises the resources of six main stakeholders. 
The first is connectivity to the targeted groups in environmental education, such as children, adolescents, communities, and the general public. Even though the primary target participants for environmental education are children, KOPHI also includes adolescents. In this context as 'educators', KOPHI staff position themselves as the 'big brothers/sisters' to the children, while the youth participants are the 'little brothers/sisters'. With a relationship such as this, KOPHI is able to strengthen emotional bonding and interaction amongst the participants, which facilitates the learning process. Creative games as an approach to learning, facilitates the delivery of messages and the learning content, which in turn can be internalized and practiced.

Unlike building a relationship and a close bond with children, KOPHI plays the role of a 'community' that has a stock of knowledge for youth. In this context, KOPHI socializes environmental management knowledge and practices like making bio-pore absorption holes and biogas as an entry point to foster a pro-environmental consciousness amongst community members. When this consciousness can be transferred, then it will be followed with collective actions on conserving the natural resources managed by the community.

While children and community members are directly approached through face-to-face interaction, the general public, in particular youth are approached using online media. Most youth can easily access online social media. Thus, the delivery of messages on environmental education using online media is more effective. The Media and Communication Division was established to strengthen the relationship with these groups. This division consists of creative members with advanced skills in selecting suitable media for use. They then develop plans, and convey messages on environmental education to the public. Although it is difficult to measure the effectiveness of online media, it is easy to gauge the number of people accessing and following the KOPHI online media.

The second is the relationship with schools in delivering environmental education covering primary schools, junior high schools, and senior high schools. Environmental education cannot be delivered successfully to youth and children without active participation of the schools. In view of this, KOPHI fosters more collaboration with chosen educative institutions as an arena for conducting environmental education. KOPHI Jakarta for instance has strong partnerships with some secondary schools for transferring skills on bio-pore absorption holes. The West Java and Yogyakarta chapter have collaborated with a number of primary schools, delivering programs through games, adventures, and creating recycled artworks from used goods.

In addition, schools that are involved in the actions are very welcome to the environmental education provided to their students. The experience of KOPHI Yogyakarta in working with Junior High School 8 Yogyakarta, for instance, demonstrated that the timing of the activity is an important consideration as they had to find free time slots within the school-hours. Moreover, all teachers were active in the environmental education as in the experience of KOPHI Jakarta in collaborating with Regina Pacis Senior High School.

The third is the relationship with local NGOs. Most actions and programs involve local NGOs in the same area or province of a KOPHI local chapter. For instance, KOPHI developed the "Piknik Koin Lestari" (Conservation Coin Picnic) program in Yogyakarta in partnership with "Coin a Chance" (CAC), a youth NGO that works in education and advocacy for children living in poverty. CAC is an action for collecting unused coins, where the collected coins are used to help needy childrenand those vulnerable to dropping out of school. KOPHI developed the program Piknik Koin Lestari for the CAC target group by providing environmental educational tours. Through this partnership, KOPHI has been able to utilize resources of local NGOs in promoting environmental education for children.

The cooperation with local NGOs is sustained through KOPHI's involvement in collaborative actions. KOPHI Yogyakarta, for instance, is engaged in pro-environmental campaigns and on-street demonstrations that are initiated by other NGOs such as Earth Hour Yogyakarta, IAAS Local Chapter UGM (University of Gadjah Mada), AIESEC, GYC and other youth organizations. Mutual and common understanding amongst NGOs is significant in boosting their actions due to their intensive and frequent meetings, which is also supported by the camaraderie among activists.

The fourth is in regard to relations with government bodies. Pro-environmental actions and programs in local settings have driven KOPHI to initiate cooperation with government bodies (i.e. the Regional Board of Environment, the Ministry of Agriculture, the Ministry of Fisheries, and other government bodies affiliated with environmental issues). Government bodies usually provide in-kind donations, i.e. plant seeds, fish seeds, and materials or equipment used for making bio-pore absorption holes and the like. KOPHI does not appear to be presumptuous in accessing funding schemes from the government.

The government provides support and assistance to KOPHI because its actions and programs actually compliment government operated programs. The Regional Board of Environmental Management in Bandung in West Java, for instance, offered KOPHI West Java the use of one of its rooms as a secretariat but the offer was 
declined as the location did not support the mobility of KOPHI's staff.

The fifth is relations with university institutions. As mentioned previously, the majority of KOPHI members are students studying at university with diverse academic backgrounds. They are actually campus 'citizens', given that KOPHI often uses the available resources at university campuses where organizational activities often take place. In the annual recruitment process, interview sessions are also held at a university campus. KOPHI Jakarta frequently uses a room available at the University of Indonesia, while KOPHI Yogyakarta often makes use of room facilities available at UGM and the State University of Yogyakarta. These venues are usually used for socializing programs and conducting events, instead of using social media. KOPHI West Java for instance, was offered an opportunity by ITB (Bandung Institute of Technology) to open a booth at an exhibition in the university, even though none of KOPHI's staff study at that campus. This fact shows that universities are also platforms for KOPHI to organize their pro-environmental actions and programs. Their student status allows them to access university managed facilities.

The sixth is the relations with corporations or private companies. KOPHI forges partnerships with corporations when they require sponsors to support programs that will be run. However, some corporations also offer funding schemes to KOPHI. These sponsorships are used to fill the funding gaps, which membership fees cannot cover. However, KOPHI will only collaborate with companies that have a deep concern for the environment and conservation. However, there are not many of these corporations. KOPHI adamantly refuses cooperation with corporations whose operations are damaging the environment or violating the law. Before running a program, KOPHI approaches companies whose products are aligned with its conservation goals. One of KOPHI's national congresses, for instance, was sponsored by a food and beverage company and a company producing household equipment. At that time, KOPHI received sponsorship in the form of in-kind donations and money, while the companies benefitted from using the event for marketing purposes and building a pro-environmental conservation brand.

\section{Conclusion}

Youth oriented ENGOs are growing rapidly in post New Order Indonesia. Among these ENGOs, KOPHI has presented outcomes that are particularistic. KOPHI's network is developing in major cities in Indonesia and its membership continues to grow through a systematic and routine recruitment process. Its conservation activities are able to involve children, adolescence and communities in a number of cities. All programs and organization activities are self-financed and do not depend on foreign funding agencies. KOPHI has rapidly grown nationwide as a youth-oriented ENGO in a relatively short time.

The achievements and milestones of KOPHI are nevertheless inseparable from the three dimensions of the strategic triangle; value creation, support and legitimacy, and operational capacity. KOPHI has well-defined environmental conservation core values. The importance of conservation values is deeply embedded in KOPHI regulations (by-laws and statues), and in the interaction among members. Through daily interaction and informal regular meetings within the organization, all members are able to learn together, exchange experiences and endeavour to develop environmentally friendly attitudes and actions. Conservation values are also embodied in the environmental education for children, youth, communities, and the general public. The choice of values and conservation actions have driven the environmental movement of KOPHI, which is more 'moderate' compared to the radical advocacy oriented ENGOs.

This ENGO has legitimacy with its spirit of voluntarism, non-profit status and participatory decision-making processes. All members are selected and mobilized according to their individual interests in environmental issues and their willingness to work in a voluntary manner. The contributions in terms of the time and effort of members, who are students busy with studies, have enabled KOPHI to initiate many successful environmental actions. The organization is also supported by solid teamwork as a result of participatory consensual decision making process in the organization.

Environmental actions that are regularly initiated by this organization have strengthened the organizational identity as an ENGO driven by university-affiliated students. KOPHI has attained recognition as a sound environmental organization as seen in its competence in establishing relations and networking with various working partners. These relations are very important to KOPHI, as they enable KOPHI to implement programs and actions with the resources provided by other partners. Due to this recognition, KOPHI's partners have willingly assisted them and shared resources.

KOPHI is capable of developing the three strategic dimensions as presented in the approach above by performing its role in environmental conservation. The dynamic of the three strategic dimensions is mutually supportive and interrelated. This is clearly evident in KOPHI as an environmental organization that has rapidly 
grown and matured in mobilizing continuous environmental actions. This in turn, has fostered recognition from the public, and ultimately has contributed to conservation efforts in Indonesia.

KOPHI's success confirms that youth-oriented ENGOs have the capacity to initiate and organize continuous environmental conservation movements. Using the conceptual framework of the strategic triangle, a similar analysis can be applied to a number of other youth-oriented ENGOs that have grown rapidly since Indonesia entered the era of democracy. Their success or failure in organizing environmental actions may be an indication of the sustainability of environmental movements among youth and also shows their contributions to the protection and preservation of the environment and natural resources both at the local and global level.

\section{Acknowledgments}

This research was carried out with the support of the "In Search of Balance" Program, collaboration between Gadjah Mada University, Indonesia and the University of Agder, Norway. The author would like to extend his gratitude to Meredian Alam, Fuji R. Riyanto, Sidiq H. Madya, Rizky Intan and Adityo Nugroho for their assistance in doing fieldwork.

\section{References}

Brown, L. D., \& Moore, M. H. (2001). Accountability, Strategy, and International Nongovernmental Organizations. Nonprofit and Voluntary Sector Quarterly, 30(3), 569-587. http://dx.doi.org/10.1177/0899 764001303012

Castells, M. (2010). The Power of Identity. Oxford: Wiley-Blackwell, A John Wiley \& Sons, Ltd., Publication.

Edwards, M. (1995). Non-governmental Organizations, Performance and Accountability, Beyond the Magic Ballet. London: Earthscan Publication Ltd. \& Save the Children.

Eldridge, P. J. (1995). Non-Government Organizations and Democratic Participation in Indonesia. Kuala Lumpur: Oxford University Press.

Hendarti, L., \& Ko, N. (2005). Environmental Education by NGOs in Indonesia. In K. Nomura, \& L. Hendarti (Eds.), Environmental Education and NGOs in Indonesia. Jakarta: Yayasan Obor Indonesia.

Hulme, D., \& Edwards, M. (Eds.). (1997). NGOs, States and Donors, Too Close for Comfort? New York: St. Martin's Press \& Save the Children.

Maohong, B. (2009). Environmental NGOs in Transforming China. Nature and Culture, 4(1), 1-16. http://dx.doi.org/10.3167/nc.200

Moore, M. H. (2000). Managing for value: Organizational strategy in for-profit, non profit, and governmental organizations. Nonprofit and Voluntary Sector Quarterly, 29(Suppl.), 183-204. http://dx.doi.org/10.1177/ 0899764001303012

Nilan, P. (2015). Discourses of Non-Formal Pedagogy in Two Youth-Oriented Indonesian Environmental NGOs. Asian Social Science, 11(21), 162-173. http://dx.doi.org/10.5539/ass.v11n21p162

Nomura, K. (2007). Democratization and Environmental Non-Governmental Organizations in Indonesia. Journal of Contemporary Asia, 37(4). http://dx.doi:10.1080/00472330701546566

Nomura, K., \& Abe, O. (2001). The Role of Networks in Promoting Environmental Education by NGOs in Asia: from a Viewpoint of International Cooperation. International Review for Environmental Strategies, 2(1), 107-125. Retrieved from http://pub.iges.or.jp/modules/envirolib/view.php?docid=411

Nomura, K., \& Hendarti, L. (Eds.). (2005). Environmental Education and NGOs in Indonesia. Jakarta: Yayasan Obor Indonesia.

Nomura, K., Hendarti, L., \& Abe, O. (2003). NGO Environmental Education Centers in Developing Countries: Role, Significance and Keys to Success, from a 'Change Agent' Perspective. International Review for Environmental Strategies, 4(2), 165-182. Retrieved from http://pub.iges.or.jp/modules/envirolib/view.php? docid $=432$

Paloniemi, R., \& Valnio, A. (2011). Why Do Young People Participate in Environmental Political Action? Environmental Values, 20, 397-416. http://dx.doi:10.3197/096327111X13077055166108

Rootes, C. (2004). Environmental Movements. In D. A. Snow, S. A. Soule, \& H. Kriesi (Eds.), The Blackwell Companion to Social Movements. Oxford: Blackwell Publishing Ltd.

Sinanu, F. (2006). Coming of Age: Indonesia's environment network faces dilemmas as it turns 25. Inside Indonesia: Bulletin of the Indonesia Resources and Information Programme, July-September, 28-29. 
Retrieved from http://nla.gov.au/nla.obj-114119229/view;jsessionid=t93ga4dhjqn7h02mhrkrhl8\#page/n30/ mode/lup

Stake, R. E. (1995). The Art of Case Study Research. London: Sage Publications.

Suharko. (2005). Merajut Demokrasi, Hubungan NGO, Pemerintah, dan Pengembangan Tata Pemerintahan Demokratis (1966-2001). Yogyakarta: Tiara Wacana.

Tilbury, D., Goldstein, W., \& Ryan, L. (2003). Towards Environmental Education for Sustainable Development: The Contributions of NGOs in the Asia-Pacific Region. International Review for Environmental Strategies, 4(1), 59-73. Retrieved from http://pub.iges.or.jp/modules/envirolib/view.php?docid=431

\section{Note}

Note 1. However, after mid 2000 the author could not find any further JPL activities and its old website could no longer be found. He also could not find any account or address associated to JPL through searching online media such as Facebook and Twitter, which are commonly used by ENGOs.

\section{Copyrights}

Copyright for this article is retained by the author(s), with first publication rights granted to the journal.

This is an open-access article distributed under the terms and conditions of the Creative Commons Attribution license (http://creativecommons.org/licenses/by/3.0/). 